\section{Cytotoxic Effect of Erythroxylum suberosum Combined with Radiotherapy in Head and Neck C ancer Cell Lines}

Taysa B. C. Macedo ${ }^{1}$, Silvia T. Elias², Hianne M. Torres ${ }^{1}$, Fernanda Paula Yamamoto-Silva1 , Dâmaris Silveira ${ }^{2}$, Pérola O. Magalhães ${ }^{2}$, Adriana LofranoPorto $^{2}$, Eliete N. S. Guerra², Maria Alves G. Silva ${ }^{1}$

\author{
'School of Dentistry, UFG \\ - Universidade Federal de \\ Goiás, Goiânia, GO, Brazil \\ ${ }^{2}$ Faculty of Health Sciences, \\ UnB - Universidade de Brasília, \\ Brasília, DF, Brazil
}

Correspondence: Dr. Eliete Neves Silva Guerra, SQN 205, bloco H, apto 201, Asa Norte 70843-080, Brasília, DF, Brazil. Tel: +55-61-9668-4988. e-mail: elieteneves@unb.br

\begin{abstract}
The mouth and oropharynx cancer is the $6^{\text {th }}$ most common type of cancer in the world. The treatment may involve surgery, chemotherapy and radiotherapy. More than $50 \%$ of drugs against cancer were isolated from natural sources, such as Catharanthus roseus and epipodophyllotoxin, isolated from Podophyllum. The biggest challenge is to maximize the control of the disease, while minimizing morbidity and toxicity to the surrounding normal tissues. The Erythroxylum suberosum is a common plant in the Brazilian Cerrado biome and is popularly known as "cabelo-de-negro". The objective of this study was to evaluate the cytotoxic activity of Erythroxylum suberosum plant extracts of the Brazilian Cerrado biome associated with radiotherapy in human cell lines of oral and hypopharynx carcinomas. Cells were treated with aqueous, ethanolic and hexanic extracts of Erythroxylum suberosum and irradiated at $4 \mathrm{~Gy}, 6 \mathrm{~Gy}$ and $8 \mathrm{~Gy}$. Cytotoxicity was evaluated by MTT assay and the absorbance was measured at $570 \mathrm{~nm}$ in a Beckman Counter reader. Cisplatin, standard chemotherapy, was used as positive control. The use of Erythroxylum suberosum extracts showed a possible radiosensitizing effect in vitro for head and neck cancer. The cytotoxicity effect in the cell lines was not selective and it is very similar to the effect of standard chemotherapy. The aqueous extract of Erythroxylum suberosum, combined with radiotherapy was the most cytotoxic extract to oral and hypopharynx carcinomas.
\end{abstract}

Key Words: head and neck cancer, cytotoxicity, plant extracts, radiotherapy, Brazilian Cerrado.

\section{Introduction}

Cancer is a leading cause of mortality worldwide. Among all subtypes, the carcinoma of mouth and pharynx, together, stands out as the sixth most common (1). In South America and Caribbean, cancers of mouth and pharynx rank fifth among men and sixth among women (1). A high incidence rate for oral and larynx cancer is observed in Brazil, with up to 20,000 new cases per year (2). Despite all the innovations, the life expectancy of patients still remains around $50 \%$, after 5 years of cancer diagnosis (3). There are many approaches adopted to deal with cancer, but they are always aggressive and come along with a number of side effects, which significantly reduces the patient's quality of life (3). The main treatment methods for head and neck cancer are surgery, radiotherapy, chemotherapy or a combination of two or more of these techniques (4). Radiotherapy is indicated as a treatment for head and neck cancer, especially in advanced cases, alone or combined $(4,5)$. The search for new therapies for cancer treatment should look for a balance between the ability of patients to tolerate the side effects of treatment and the potential toxicity that may occur later (6). Plant-derived products are excellent sources for discovery and development of new anticancer agents since the 60 's, with the first researches on epipodophyllotoxin and its derivatives as cytotoxic agents, until nowadays, with the study of vinca alkaloids, vinblastine, vincristine, epipodophyllotoxin and taxanes, which are natural sources of drugs with activity against cancer (7). Several studies have been conducted using products derived from plants, which are excellent sources for the development of new anticancer agents $(8,9)$. Tokgun et al. (10) pointed out that treatment with plant derivatives have fewer side effects than synthetic drugs. Therefore, the search for derivatives from natural compounds to treat cancer seems promising. Recent studies with plant extracts from different regions, came up highlighting the cytotoxic effects in cell lines of different cancer types, like breast, esophagus, stomach, lung and others (10-12).

Regarding head and neck tumors, in the past 20 years, chemoradiotherapy was established as the most conservative treatment (13). The combination of radiotherapy with natural extracts also appears to be an important tool in the treatment of such tumors. Kotowski et al. (14) studied the effect of sulforaphane added to radiation exposures in cell lines of head and neck cancer. The experiment showed that the combination of sulforaphane, 
a compound derived from broccoli and other cruciferous vegetables, and radiation leads to a stronger inhibition of cell proliferation and clonogenic survival compared to the use of single treatments. The Cerrado biome is the second largest one in Brazil, extending for about 2 million square kilometers (15), but it appears that little is known about the biological potential of this biome. In the Brazilian Cerrado there are promising possibilities to be investigated. De Mesquita et al. (8) tested 412 extracts of 50 plants from Cerrado used in traditional medicine, in tumor cell lines from human cervix carcinoma, melanoma, leukemia and brain. The study showed an antiproliferative potential for 28 extracts.

The Erythroxylum suberosum (E. suberosum) is a common plant in the Cerrado biome, especially in the State of Mato Grosso do Sul, and it is popularly known by "cabelo-de-negro". A supra-additive cytotoxic effect in head and neck carcinoma cell lines has already been shown by Erythroxylum suberosum followed by irradiation with a single dose of $2 \mathrm{~Gy}$ (16). In view of the biological potential of plants from the Cerrado biome, this paper aims to evaluate the cytotoxic activity of Erythroxylum suberosum plant extracts combined with radiotherapy in human cell lines of oral and hypopharynx carcinomas.

\section{Material and Methods}

\section{Plant Material and Extraction}

For the experiments were used aqueous, ethanolic and hexanic extracts from the leaves of Erythroxylum suberosum A. St.-Hil. collected from the Cerrado biome in the city of Brasilia, Brazil and its surroundings. Different types of solvent can separate the substances in the plant according to their polarity, so the hexane extract has the most non-polar compounds and the aqueous extract the polar substances. The voucher herbarium specimens were deposited in the herbarium of the University of Brasilia, Brazil (UB 2192). All necessary permits were obtained previously of this experimental study.

To obtain the extracts, the leaves of E. suberosum passed drying process at room temperature and spraying process. Subsequently, they were submitted to extraction by passive maceration, using hexane solvent followed by ethanol, to obtain the hexane and ethanol extracts. The obtained extractive solutions were concentrated to dryness under vacuum, at about $40{ }^{\circ} \mathrm{C}$ in rotaevaporator. The aqueous extract was obtained by infusing the dried and pulverized leaves in distilled water $(3.0 \mathrm{~L})$ at approximately $70{ }^{\circ} \mathrm{C}$, cooled to approximately $40^{\circ} \mathrm{C}$ and subjected to filtration. The resulting extraction solution was maintained at -20 ${ }^{\circ} \mathrm{C}$ and subjected to lyophilization process, producing a powder that maintains the active ingredient for a long period of time.

\section{Cell Culture}

Cell lines of oral squamous cell carcinoma (SCC-9), hypopharynx squamous cell carcinoma $(\mathrm{FaDu})$, and human keratinocyte ( $\mathrm{HaCaT})$ were used. All cell lines are described in ATCC (American Type Culture Collection). The cells were stored in an incubator at $37^{\circ} \mathrm{C}$ and $5 \%$ of $\mathrm{CO}_{2}$. For FaDu cells and $\mathrm{HaCaT}$ the cell culture medium was Dulbecco's Modified Eagle Medium (DMEM, Sigma-Aldrich) supplemented with fetal bovine serum at $10 \%$ and $1 \%$ penicillin and streptomycin. For cultivation of SCC-9 was used DMEM/ F12 ratio (1:1) supplemented with the above supplements and hydrocortisone. For trypsinization of the cells was used 0.25\% trypsin with $0.03 \%$ EDTA.

\section{Cytotoxicity assay}

SCC-9, FaDu, HaCaT cell lines were plated at a concentration of $5 \times 10^{3}$ cells per well in 96 -well plates and after $24 \mathrm{~h}$ treated with the extracts at a concentration of $500 \mu \mathrm{g} / \mathrm{mL}$, as described in a former study (16). Cisplatin (Citoplax, $1 \mathrm{mg} / \mathrm{mL}$; Bergamo, Taboão da Serra, SP, Brazil) at a $50 \mu \mathrm{g} / \mathrm{mL}$ was used as a positive control. For negative control, the cells were treated only with the corresponding solvent used for dilution of the extracts (milliq water for aqueous extract and DMSO/ethanol 2:3 for hexanic and ethanolic extracts). After $24 \mathrm{~h}$ of treatment the culture with the extract was aspirated and the cells were maintained in $100 \mu \mathrm{L}$ PBS (Phosphate Buffered Saline) for irradiation.

\section{Irradiation}

Irradiation was performed at the Department of Radiotherapy- CACON, University Hospital of Brasilia using a Siemens Primus Linear Accelerator apparatus (Siemens, Germany), in conventional radiation, with $6 \mathrm{mV}$ photon beams at fractional doses of 4, 6 and 8 Grays. For irradiation, the culture medium with treatment and controls were removed and all wells were added with $100 \mu \mathrm{L}$ of PBS 1x. After irradiation, the PBS was removed and cells maintained in 100 $\mu \mathrm{L}$ of culture medium without any treatment for more $24 \mathrm{~h}$.

\section{MTT Assay}

The cell viability was assessed by MTT test [3-(4,5-dimethylthiazol-2-yl) -2,5-diphenyltetrazolium bromide], and the absorbance measured by Beckman Counter reader at $570 \mathrm{~nm}$ (Beckman Coulter Inc., Brea, CA, USA). Cells treated only with the suitable solvent for each extract and irradiation were considered as negative control $(100 \%)$. All other percentages were calculated compared to the control cells. The experiments were performed at least three times independently and in triplicate.

\section{Statistical Analysis}

Statistical analysis was performed using GraphPad 
Prism version 5.0 and applied one-way ANOVA followed by Tukey's multiple comparison test. It was considered statistically significant results for $p<0.05$ compared with the control group.

\section{Results}

For oral cancer cell line (SCC-9), cisplatin in combination with radiotherapy at the dose of $4 \mathrm{~Gy}$ radiation resulted in approximately $36 \%$ viable cells, while the pretreatment with aqueous extract from E. suberosum (ESA) proved to be more effective, leaving only $27 \%$ viable cells. Similar results were found in the combination of ESA with the dose of $8 \mathrm{~Gy}$ (31\% viable cells). Unlike the aqueous extract, the pretreatment of SCC-9 with the ethanolic (ESE) and hexanic (ESH) extracts, cell viability was about $50 \%$, but the results were not considered statistically significant. For the ethanol extract of $E$. suberosum (ESE), the best result was under irradiation of $8 \mathrm{~Gy}$, which resulted in approximately $54 \%$ of cytotoxicity, while for the hexane extract of the plant (ESH) under irradiation of 4 Gy the result was 63\% cytotoxicity (Fig. 1).

The hypopharynx carcinoma cells ( $\mathrm{FaDu}$ ) appear to be more sensitive to the combination of $E$. suberosum extracts and the $8 \mathrm{~Gy}$ radiation dose. In the other dose only the cisplatin/radiotherapy 6 Gy combination showed strong toxicity, with only $28.4 \%$ viable cells. The aqueous extract showed the highest cytotoxic activity, demonstrating viability rates corresponding to 34\%, 39\% and 26\% when associated with doses of $4 \mathrm{~Gy}, 6 \mathrm{~Gy}$ and $8 \mathrm{~Gy}$, respectively. For the cells under an 8 Gy radiotherapy, the ethanolic extract (ESE) also showed high toxicity, resulting in a

SCC-9

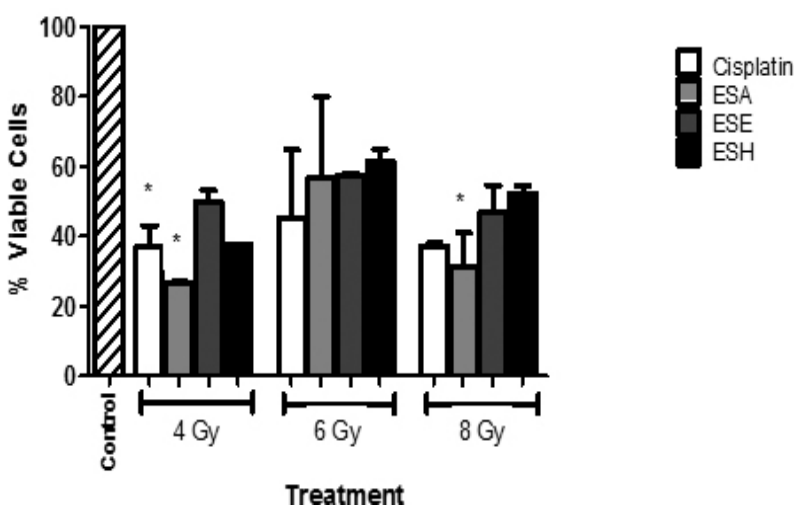

Figure 1. Cytotoxicity in oral carcinoma cells (SCC-9) treated with aqueous (ESA), ethanolic (ESE) and hexanic (ESH) extracts of Erythroxylum suberosum and irradiated with 4 Gy, 6 Gy and 8 Gy. Control: solvent extracts (milliq water to aqueous extract and DMSO/ Ethanol for ethanolic and hexanic) and radiation. The absorbance of control cells was stabilized as 100\% viability. The results are representative of at least three independent experiments in triplicate and show the mean \pm SD. ${ }^{*} p<0.05$ vs. control. reduction in the number of viable cells (28\%). This behavior was very similar to the one observed in cells treated with chemotherapy, 22\% cell viability. Only ESH did not show results of toxicity considered statistically significant under 8 Gy irradiation (Fig. 2)

All treatments were aggressive to the keratinocyte cell line ( $\mathrm{HaCaT})$. The results that showed the highest percentage of cell viability were the ESH treatments, approximately 47\%, under 4 Gy radiation and ESE 49\% when associated with 6 Gy radiation. Previous treatments of cisplatin and the aqueous extract of $E$. suberosum associated with the 4 Gy dose, had very similar cytotoxic activity, resulting in approximately $73 \%$ of cell death. Among all treatments, cisplatin was less toxic under $8 \mathrm{~Gy}$ radiation with about 27\% viable cells (Fig. 3 ).

\section{Discussion}

This study underlines the important biological potential of E. suberosum associated with radiation for oral cancer treatment. Here was demonstrated that FaDu (hypopharynx carcinoma cell line) and SCC-9 (oral cancer cell line) treated with ESA presented similar percentage of cell toxicity (74\%). The FaDu cells were exposed to $8 \mathrm{~Gy}$ of irradiation, while SCC -9 cells were exposed to a lower radiation dosage, only $4 \mathrm{~Gy}$. Such behavior allows to infer that there is difference in behavior between head and neck carcinoma cell lines, and the combination treatment extract of $E$. suberosum and radiotherapy was more effective for the oral carcinoma cell line (SCC-9). In a similar manner, data from the $\mathrm{MACH}-\mathrm{NC}$ Collaborative Group indicated that concomitant chemotherapy and radiotherapy provided a survival benefit 
of $8.9 \%$ for oral cancer and $4 \%$ to hypopharynx tumors. This may explain the in vitro results from this study (17).

The toxicity of the radiation in cells is dose-dependent, and has the capacity of inducing sublethal damage sufficient to cause apoptosis (18). Bachaud et al. (19) pointed out that the combination of chemotherapy and radiotherapy has better anti-cancer results than from the treatments carried out with radiotherapy only. In order to reduce the side effects and toxicity caused by these conventional treatments, researchers have sought to exploit new sources of treatments, more effective and less toxic compounds. In relation to head and neck cancer using this new approach with plants, little has been published, but good results have emerged. Recently, it was found that plant extracts have strong cytotoxic potential in cell lines of various cancer types $(10,12,19)$. In addition, there is some evidence that the combination of sulforaphane extract with radiotherapy showed a better result of cytotoxicity in head and neck cancer cell lines than the use of radiotherapy only (14).

The Erythroxylum suberosum has been little studied as an antitumor drug, but it has already had its cytotoxic activity proven in FaDu cell line, with or without radiotherapy. As for the SCC-9 line, only 2 Gy of radiotherapy associated to extract was able to induce approximately $50 \%$ of cell toxicity (16). For Elias et al. (16), hexane extract showed the highest toxicity but in this study it was found that pretreatment of cells with aqueous (EDA) and ethanol (EDE) extracts showed better radiosensitizing effect in hypopharynx carcinoma cell lines $(\mathrm{FaDu})$ when associated with $8 \mathrm{~Gy}$ radiotherapy. This difference may be explained, because Elias et al. (16) used only 2 Gy radiation.

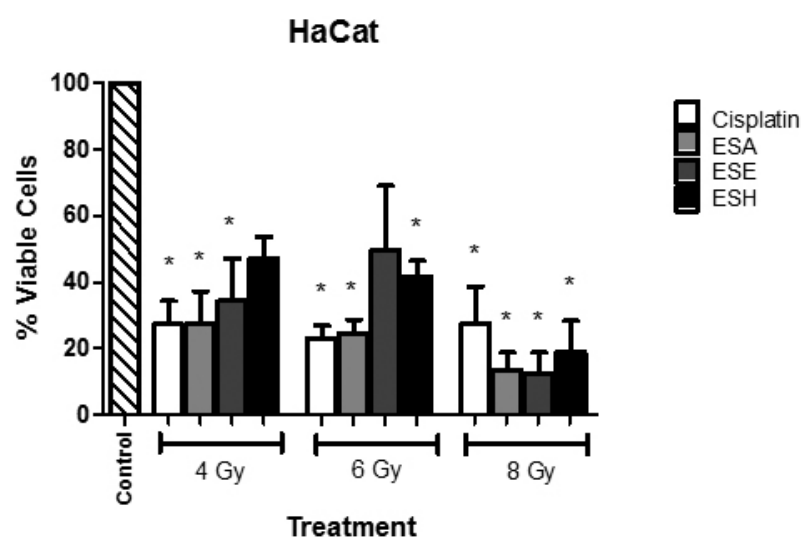

Figure 3. Cytotoxicity in human keratinocyte cells (HaCaT) treated with aqueous (ESA), ethanolic (ESE) and hexanic (ESH) extracts of Erythroxylum suberosum and irradiated with 4 Gy, 6 Gy and 8 Gy. Control: solvent extracts (milliq water to aqueous extract and DMSO/ Ethanol for ethanolic and hexanic) and radiation. The absorbance of control cells was stabilized as 100\% viability. The results are representative of at least three independent experiments in triplicate and show the mean \pm SD. ${ }^{*} \mathrm{p}<0.05$ vs. control
On oral carcinoma cell line (SCC-9), EDA associated to 4 Gy radiation was very cytotoxic, with a better result than that observed in cells treated with standard chemotherapy (cisplatin) and radiotherapy. The results showed that the treatments were not selective for the carcinoma cell lines, since they were quite aggressive to all cells, including the keratinocytes ( $\mathrm{HaCaT})$. Treatment with $\mathrm{ESH}$ and $6 \mathrm{~Gy}$ radiation showed the best result of cell viability for the $\mathrm{HaCaT}$ cells, approximately $41 \%$, also being better than in the conventional treatment with cisplatin which got only $27 \%$ of viable cells under 8 Gy radiation.

The treatment with the aqueous, ethanol and hexane extracts of Erythroxylum suberosum in head and neck cancer cells showed a possible radiosensitizing effect in vitro. The effect of cytotoxicity in the cell lines was not selective and very similar to the effect of standard chemotherapy. Aqueous extracts of Erythroxylum suberosum were the most cytotoxic extracts for oral carcinoma (SCC-9) and hypopharynx ( $\mathrm{FaDu})$, associated with radiotherapy in doses of $4 \mathrm{~Gy}$ and $8 \mathrm{~Gy}$, respectively. Among the proposed treatments, ethanol extracts of Erythroxylum suberosum showed the lowest toxicity to the keratinocyte cell line after 6 Gy of radiation.

Previous study by this group found by HPLC analysis that Erythroxylum suberosum extracts present a large number of compounds and both extracts, ethanolic and aqueous, showed similar compounds in their composition. The characteristic UV/Vis spectra of the catechin and flavonoids were confirmed by standards. It was possible to identify some peaks by comparison of commercial standards, which are catechin, epicatechin and rutin (20).

It is important to consider that plant extracts are very complex mixtures, presenting a great amount of active compounds. This is why this study was done with three different crude extracts from each plant species, each one with a different polarity. The more polar ones, which are the ethanolic and aqueous extracts, are rich in polyphenols. Flavonoids are a class of polyphenol compounds, which are widespread in the plant kingdom. These compounds present several biological activities, including antioxidant (20) and radioprotective properties (21). However, a recent report demonstrated that soy flavonoids could be a biological agent to sensitize cancer to radiation while simultaneously protecting surrounding normal tissues (22).

Some of the key components of the plant extracts evaluated in this study are triterpenes, fatty acids and long chain esters in the hexanic extracts, and flavonoids, caffeic acid derivatives and catechins in the ethanolic extracts. Specifically, lupeol acetate and $\alpha$ - and $\beta$-amyrin have been previously isolated from the hexanic extract from Pouteria torta (23). Alkaloids were not identified in Erythroxylum sp. extracts (23). 
This study emphasizes the important biological potential of compounds obtained from the Brazilian Cerrado biome, associated with traditional cancer treatments. Thus, there is much to be researched to treat cancer, provide greater control of the disease and reduce morbidity to surrounding normal tissues.

\section{Resumo}

0 câncer de boca e de orofaringe emerge como o $6^{\circ}$ tipo de câncer mais comum no mundo. 0 tratamento pode envolver cirurgia, quimioterapia e radioterapia. Mais de 50\% das drogas com atividade de combate ao câncer foram isoladas de fontes naturais, tais como a Catharanthus roseus e a epipodofilotoxina, isolada de Podophyllum. 0 maior desafio é maximizar o controle da doença, enquanto minimiza a morbidade e toxicidade para os tecidos normais circundantes. 0 Erythroxylum suberosum é uma planta comum no bioma Cerrado brasileiro e é popularmente conhecida como "cabelo-de-negro". 0 objetivo deste estudo foi avaliar a citotoxicidade dos extratos da planta Erythroxylum suberosum do bioma Cerrado brasileiro, associados à radioterapia em linhagens celulares humanas de carcinomas de língua e de hipofaringe. As células foram tratadas com os extratos aquoso, etanólico e hexânico do Erythroxylum suberosum e irradiadas com $4 \mathrm{~Gy}, 6$ Gy e 8 Gy. A citotoxidade foi avaliada pelo ensaio de MTT e a absorvância foi medida a $570 \mathrm{~nm}$ em uma leitora Beckman. A cisplatina, quimioterápico padrão, foi utilizada como controle positivo. 0 uso de extratos de Erythroxylum suberosum mostrou potencial efeito radiosensibilizante in vitro no câncer de cabeça e pescoço. 0 efeito da citotoxicidade nas linhagens foi de forma não seletiva e muito semelhante ao efeito da quimioterapia padrão. 0 extrato aquoso de Erythroxylum $\vec{s}$ suberosum, combinado com radioterapia, foi o extrato mais citotóxico ¿ para os carcinomas de língua e hipofaringe, associados à radioterapia.

\section{Acknowledgements}

This research was funded by the National Scientific and Technological Development Council - CNPq (Notice MCT/CNPq/FNDCT/FAPs/MEC/ CAPES/ PRO-CENTRO-OESTE No. 031/2010- project 564658/2010-3) and the Institutional Program of Scientific Initiation Scholarships (PIBIC). To doctors Luis Felipe Oliveira e Silva and Samuel Avelino from the Radiotherapy Department of CACON - HUB-UnB for their help during the irradiation.

\section{References}

1. Warnakulasuriya S. Global epidemiology of oral and oropharyngeal cancer. Oral Oncol 2009;45:309-16.

2. INCA. National Cancer Institute. Brazilian cancer incidence. City; Accessed February 15, 2014.

3. Shah JP, Gil Z. Current concepts in management of oral cancer-surgery. Oral Oncol 2009;45:394-401.

4. Pedruzzi PA, Kowalski LP, Nishimoto IN, Oliveira BV, Tironi F, Ramos $\mathrm{GH}$. Analysis of prognostic factors in patients with oropharyngeal squamous cell carcinoma treated with radiotherapy alone or in combination with systemic chemotherapy. Arch Otolaryngol Head Neck Surg 2008;134:1196-1204.

5. Tobias JS, Monson K, Gupta N. Chemoradiotherapy for locally advanced head and neck cancer: 10-year follow-up of the UK Head and Neck (UKHAN1) trial. Lancet Oncol 2010;11:66-74.

6. Cabrera AR, Yoo DS, Brizel DM. Contemporary radiotherapy in head and neck cancer balancing chance for cure with risk for complication. Surg Oncol Clin N Am 2013;22:579-598.
7. Srivastava V1, Negi AS, Kumar JK, Gupta MM, Khanuja SP. Plantbased anticancer molecules: a chemical and biological profile of some important leads. Bioorg Med Chem 2005;13:5892-5908.

8. de Mesquita ML, de Paula JE, Pessoa C, de Moraes MO, Costa-Lotufo LV, Grougnet $R_{1}$ et al.. Cytotoxic activity of Brazilian Cerrado plants used in traditional medicine against cancer cell lines. J Ethnopharmacol 2009;123:439-445.

9. Elias ST, Diniz J, Almeida RS, Alvarenga N, Simeoni LA, Silveira D, et al.. Cytotoxic effect of tobacco extracts on human oral squamous cell carcinoma cell-line. Oral Oncol 2010;46:869-873.

10. Tokgun O, Akca H, Mammadov R, Aykurt C, Deniz G. Convolvulus galaticus, Crocus antalyensis, and Lilium candidum extracts show their antitumor activity through induction of p53-mediated apoptosis on human breast cancer cell line MCF-7 cells. J Med Food 2012;15:10001005.

11. Liu W1, Li SY, Huang XE, Cui JJ, Zhao T, Zhang H. Inhibition of tumor growth in vitro by a combination of extracts from Rosa roxburghii Tratt and Fagopyrum cymosum. Asian Pac J Cancer Prev 2012;13:2409-2414.

12. Song M, Park DK, Park HJ. Antrodia camphorata grown on germinated brown rice suppresses melanoma cell proliferation by inducing apoptosis and cell differentiation and tumor growth. Evid Based Complement Alternat Med 2013;2013:321096.

13. Zhang N, Erjala K, Kulmala J, Qiu X, Sundvall M, Elenius $K$, et al.. Concurrent cetuximab, cisplatin, and radiation for squamous cell carcinoma of the head and neck in vitro. Radiother Oncol 2009;92:388392.

14. Kotowski U, Heiduschka G, Brunner M, Czembirek C, Eder-Czembirek C, Schmidt R, et al.. Radiosensitization of head and neck cancer cells by the phytochemical agent sulforaphane. Strahlenther Onkol 2011;187:575-580.

15. Ratter JA, Ribeiro JF, Bridgewater S. The Brazilian Cerrado vegetation and threats to its biodiversity. Ann Bot 1997;80:223-230.

16. Elias ST, Borges GA, Amorim DA, Rêgo DF, Simeoni LA, Silveira D, et al.. Radiation induced a supra-additive cytotoxic effect in head and neck carcinoma cell lines when combined with plant extracts from Brazilian Cerrado biome. Clin Oral Investig 2015;19:637-646.

17. Pignon JP, Bourhis J, Domenge C, Designé L. Chemotherapy added to locoregional treatment for head and neck squamous-cell carcinoma: three meta-analyses of updated individual data. MACH-NC Collaborative Group. Meta-Analysis of Chemotherapy on Head and Neck Cancer. Lancet 2000;355:949-955.

18. Zheng $X K$, Chen $L H$, Wang WJ, Ye F, Liu JB, Li QS, et al.. Impact of prolonged fraction delivery times simulating IMRT on cultured nasopharyngeal carcinoma cell killing. Int J Radiat Oncol Biol Phys 2010;78:1541-1547.

19. Bachaud JM, Cohen-Jonathan E, Alzieu C, David JM, Serrano E, Daly-Schveitzer N. Combined postoperative radiotherapy and weekly cisplatin infusion for locally advanced head and neck carcinoma: final report of a randomized trial. Int J Radiat Oncol Biol Phys 1996;36:9991004.

20. Pietta PG. Flavonoids as antioxidants. J Nat Prod 2000;63:1035-1042.

21. Shimoi K, Masuda S, Furugori M, Esaki S, Kinae N. Radioprotective effect of antioxidative flavonoids in gamma-ray irradiated mice. Carcinogenesis 1994;15:2669-2672.

22. Hillman GG, Singh-Gupta V, Runyan L, Yunker CK, Rakowski JT, Sarkar $\mathrm{FH}$, et al.. Soy isoflavones radiosensitize lung cancer while mitigating normal tissue injury. Radiother Oncol 2011;101:329-336.

23. Silva CAM, Simeoni LA, Silveira D. Genus Pouteria: chemistry and biological activity. Rev Bras de Farmacognosia 2009;19:501-509.

Received January 9, 2015 Accepted January 22, 2016 